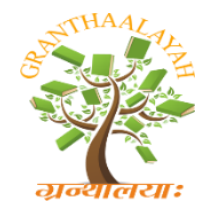

Management

\title{
A STUDY ON PREFERENCE OF POLICYHOLDERS ABOUT PUBLIC AND PRIVATE LIFE INSURANCE COMPANIES IN TIRUNELVELI DISTRICT
}

\author{
Dr. I. Meenakshi ${ }^{* 1}$ \\ ${ }^{* 1}$ Department of Commerce, St. Xavier's college, Palayamkottai, India
}

\begin{abstract}
There are currently, a total of 24 life insurance companies in India. Of these, Life Insurance Corporation of India (LIC) is the only public sector insurance company. All others are private insurance companies. The Life Insurance Corporation of India (LIC) is the largest life insurance company in India and also the country's largest investor. More and more new private insurance companies are coming up year after year. And, these new and private life insurance companies adopt aggressive marketing strategies to introduce their products and to tap the potential policyholders. It is witnessed that new policies like ULIPs are introduced by these new private life insurance companies. It is in this concept this study has been undertaken to assess and analyze the preference of policyholders towards insurance services offered by public and private life insurance companies in Tirunelveli district.
\end{abstract}

Keywords: Life Insurance; Policyholders; Preference.

Cite This Article: Dr. I. Meenakshi. (2018). "A STUDY ON PREFERENCE OF POLICYHOLDERS ABOUT PUBLIC AND PRIVATE LIFE INSURANCE COMPANIES IN TIRUNELVELI DISTRICT.” International Journal of Research - Granthaalayah, 6(4), 105-110. https://doi.org/10.29121/granthaalayah.v6.i4.2018.1485.

\section{Introduction}

Indian insurance market has been going through a transition phase in the wake of LPG (Liberalization, Privatization and Globalization). In the pre-liberalization era, LIC of India was the monopoly in the insurance sector in India. It was not duly concerning about customer services. The main drawback was the lack of proper information about the available products and services and the absence of any competition. The products were also limited and insurance was mainly purchased for risk covering. But in the year 2000, the insurance sector was opened up for private players. The insurance sector has changed drastically after this. The new insurance companies concentrate more on the areas which were uncovered by LIC. The impact of private players can be felt in the areas like product innovation, promotion and service standards. 


\section{Objectives of the Study}

The following are the objectives of the study:

1) To study the preference of policyholders of both Public and private life insurance services.

2) To find out the problems faced by the policyholders in availing both life insurance services.

\section{Operational Definition of Concepts}

\section{Life Insurance}

Life insurance is a contract between a person and the insurance company covering either the life term or a fixed number of years.

\section{Policyholder}

Policyholder means one who takes the policy from the insurance company. A policyholder takes the policy based on his age and income. The policyholders get the maturity value on the maturity date. If death occurs, the nominee of the policyholder receives the claim amount from the insurance company.

\section{Preference of Policyholder}

Preference of policyholders denotes the way in which policyholders look at the various aspects related to other avenues of savings.

\section{Review of Literature}

Kauret al., (2010) carried out a study entitled, "A Study on Customer Satisfaction with Life Insurance in Chandigarh, Tricity", observed that policyholders are more satisfied with the policy features, price, maturity benefits and tax saving content.

Pushp Deep Dagar and Sunil Phougat (2011) in their article on "Impact of Privatization of Life Insurance Sector on Consumer" reveal that the policyholders are more satisfied with the services of private insurers than LIC with regard to the attractive policy offerings with low premium and long period and their consistent services.

Uma et al., (2011) in their article titled, "A Survey of Life Insurance Customers Awareness, Perception and Preferences", observes that a majority of customers are satisfied the policy features whereas few customers are dissatisfied with the incomplete information provided to them and suppression of information about the policy terms and conditions.

\section{Research Methodology}

The survey is conducted on the target population of the District of Tirunelveli. Data were collected from 300 policyholders from LIC of India. With regard to sample respondents, disproportionate stratified random sampling was adopted.

\section{Data Analysis and Interpretation}


Table 1: Preference of Policyholders of LIC

\section{Source: Primary Data}

\begin{tabular}{|l|l|l|l|}
\hline Sl.No. & Preference of LIC Policyholders & Garret Mean Score & Rank \\
\hline 1 & Better Service & 60.25 & I \\
\hline 2 & Attractive Schemes & 55.48 & II \\
\hline 3 & Diversified Policies & 53.15 & III \\
\hline 4 & Less Insurance Premium & 52.20 & IV \\
\hline 5 & Quick Maturity Period & 49.41 & V \\
\hline 6 & Claim Settlement & 47.13 & VI \\
\hline 7 & Growth in Investment & 41.71 & VII \\
\hline 8 & Flexibility & 40.15 & VIII \\
\hline
\end{tabular}

Table 1 clearly shows that the preference of LIC policyholders to select insurance services with respective GARRET mean score and ranks. It is obvious from the table that of the eight items, 'better service' is ranked first with the highest Garret mean score of 60.25 which is followed by 'attractive schemes' with a mean score of 55.48 'diversified policies' has been ranked third with a mean score of 53.15 which is followed by 'Less Insurance Premium' with a mean score 52.20. 'Quick maturity period' has been ranked fifth with a mean score of 49.41. 'Claim settlement' has been ranked sixth with the mean score of 47.13 , followed by 'Growth in investment' which ranked seventh with the mean score of 41.71. 'Flexibility' has been ranked as the least Garret mean score of 40.15

Table 2: Preference of Policyholders of PLICs

\begin{tabular}{|l|l|l|l|}
\hline Sl.No. & Preference of PLICs Policyholders & Garret Mean Score & Rank \\
\hline 1 & Claim Settlement & 62.38 & I \\
\hline 2 & Better Service & 54.34 & II \\
\hline 3 & Attractive Schemes & 53.13 & III \\
\hline 4 & Diversified Policies & 52.64 & IV \\
\hline 5 & Less Insurance Premium & 50.34 & V \\
\hline 6 & Quick Maturity Period & 43.92 & VI \\
\hline 7 & Flexibility & 43.69 & VII \\
\hline 8 & Growth in Investment & 42.96 & VIII \\
\hline
\end{tabular}

\section{Source: Primary Data}

Table 2 clearly shows that the preference of PLICs policyholders to select insurance services with respective GARRET mean score and ranks. It is obvious from the table that of the eight items, 'Claim settlement' is ranked first with the highest Garret mean score of 62.38 which is followed by 'Better service' with a mean score of 54.34 'Attractive Schemes' has been ranked third with a mean score of 53.13 which is followed by 'Diversified policies' with a mean score 52.64. 'Less Insurance Premium' has been ranked fifth with a mean score of 50.34. 'Quick maturity period' has been ranked sixth with the mean score of 43.92, followed by 'Flexibility' which ranked seventh with the mean score of 43.69. 'Growth in investment' has been ranked as the least Garret mean score of 42.96 .

Table 3: Problems Faced by Policyholders of LIC 


\begin{tabular}{|l|l|l|l|}
\hline $\begin{array}{l}\text { SI. } \\
\text { No. }\end{array}$ & Problems & Garret Mean Score & Rank \\
\hline 1 & Waiting for a long time & 65.22 & I \\
\hline 2 & Inadequate staff & 63.11 & II \\
\hline 3 & Lack of proper direction by office staff & 61.12 & III \\
\hline 4 & Agents' belated service & 58.26 & IV \\
\hline 5 & Unsatisfactory services & 53.21 & V \\
\hline 6 & Unfriendly staff & 51.93 & VI \\
\hline 7 & Inadequate infrastructure & 45.12 & VII \\
\hline 8 & Exaggeration of benefits & 38.76 & VIII \\
\hline 9 & No proper and timely reminders & 37.56 & IX \\
\hline 10 & No complete information about insurance service & 32.66 & X \\
\hline
\end{tabular}

\section{Source: Primary Data}

Table 3 clearly shows the customers' problems while availing insurance services with respective GARRET mean score and ranks. It is obvious from the table that of the ten identified problems; 'waiting for a long time' is ranked first with the highest Garret mean score of 65.22 which is followed by 'inadequate staff' with a mean score of 63.11. The 'Lack of proper direction by office staffs' has been ranked third with a mean score of 61.12 which is followed by 'agents belated service' with a mean score 58.26. The 'unsatisfactory services' has been ranked fifth with a mean score of 53.21. 'Unfriendly staff' has been ranked sixth with the mean score of 51.93, the problem 'inadequate infrastructure 'has been ranked seventh with the mean score of 45.12. 'Exaggeration of benefits' has been ranked eighth with the mean score of 38.76 followed by 'no proper and timely reminders' which has been ranked ninth with the mean score of 37.56. 'No complete information about insurance service' has been ranked as the last one with the least Garret mean score of 32.66.

Table 4: Problems Faced by Customers of PLICs

\begin{tabular}{|l|l|l|l|}
\hline Sl.No. & Problems & Garret Mean Score & Rank \\
\hline 1 & Inadequate staff & 57.07 & I \\
\hline 2 & Unsatisfactory services & 55.51 & II \\
\hline 3 & Waiting for a long time & 55.21 & III \\
\hline 4 & Inadequate infrastructure & 53.60 & IV \\
\hline 5 & Lack of Proper direction by office staff & 53.17 & V \\
\hline 6 & Unfriendly Staff & 51.69 & VI \\
\hline 7 & Exaggeration of benefits & 50.79 & VII \\
\hline 8 & Agents' belated service & 46.08 & VIII \\
\hline 9 & No Proper and Timely Reminders & 39.15 & IX \\
\hline 10 & No complete information about insurance service & 24.37 & X \\
\hline
\end{tabular}

\section{Source: Primary Data}

Table 4 clearly shows the customers' problems while availing insurance services with respective GARRET mean score and ranks. It is obvious from the table that of the ten identified problems, 'inadequate staff' is ranked first with the highest Garret mean score of 57.07 which is followed by 'unsatisfactory services' with a mean score of 55.51. 'Waiting for a long time' has been ranked third with a mean score of 55.21 which is followed by 'inadequate infrastructure' with a mean score 53.60. The problem 'lack of proper direction by office staff' has been ranked fifth with a 
mean score of 53.17. 'Unfriendly staff' has been ranked sixth with the mean score of 51.69, followed by 'exaggeration of benefits 'has been ranked seventh with the mean score of 50.79. 'Agents in prompt service' has been ranked eighth with the mean score of 46.08 followed by 'No proper and timely reminders' which has been ranked ninth with the mean score of 39.15. 'No complete information about insurance services' has been ranked with the least Garret mean score of 24.37 .

\section{Suggestions Offered by LIC Policyholders}

Most of the LIC customers suggest that staff should do their work properly and they should improve their knowledge and staff must be present in office on time and they should provide friendly service to customers, reminder should be sent properly and communication system should be developed. LIC of India should meet the agents monthly and customers should not be made wait for long time in a counter.

A large number LIC of India respondents suggest that LIC should provide the information to customers through SMS; agents should provide accurate information to the customers; quick claim settlement should be made by LIC for its customers; advertisement of LIC should be strengthened as they felt that there is no enough advertisement about new policies; customers should be given still better service and in private life insurance companies and customers should be well received and be given due respect.

\section{Suggestions Offered by Customers of PLICs}

Most of the PLICs customers suggest that own building is a must for every branch at every place for private life insurance companies of India; bonus rate has to be increased and rate of interest on loan has to be curtailed; latest technology on IT can be utilized to the optimum, E.office governance, paperless office and 'Go Green' project may be implemented by PLICs of India; prompt and proper reminders should given for renewal premium payment; and more efforts especially promotional efforts should be taken by PLICs to attract more potential customers towards them.

A large number of customers of PLICs suggest that staff should serve still friendlier; information about policy should be clearly explained to the customers and the policy maturity amount should be settled within the time and there must be no delay in claim/final settlement; counter facilities should be improved in the branch offices of PLICs. Tangibility aspects should be developed in branch offices of PLICs and establish more number of branch office in Tirunelveli District.

\section{Conclusion}

The researcher is confident that this small piece of research work on preference of policyholders of LIC and PLICs about life insurance services of India will definitely kindle a keen interest in the minds of the budding and future researchers. The researcher takes pride in concluding the study with her vision of 'India' with fully, insured individuals by 2020' since life insurance protects every individual both during one's existence and even beyond one's existence. 


\section{References}

[1] Chawala Sonia \& Singh Fulbag(2008), "SERVICE QUALITY PERCEPTION OF LIFE INSURANCE POLICYHOLDERS IN NORTHERN INDIA:PRE-PRIVATIZATION VS.POST PRIVATIZATION" the ICFAI University Journal of Marketing Management, Vol.7,No. 4, pp 2353.

[2] Kaur, ParamjitNegi and Meenakshi (2010), "A STUDY ON CUSTOMER SATISFACTION WITH LIFE INSURANCE IN CHANDIGARH TRICITY”, Journal of Institute of Management Technology, Vol.14 (2).

[3] MehlwalGeetanjali,(2006), "The FACE OF THE INSURANCE INDUSTRY IN INDIA",INSURANCE CHRONICLE,(Jan)pp.57-63

[4] Push Deep Dagar and Sunil Phougat (2011), "IMPACT OF PRIVATIZATION OF LIFE INSURANCE SECTOR ON CONSUMER”, Southern Economist, Vol. 45 (23), pp. 38 - 42.

[5] Uma, K., S. Selvanayaki and M. Sankar (2011), "A SURVEY OF LIFE INSURANCE CUSTOMER'S AWARENESS, PERCEPTION AND PREFERENCES”, Marketing Mastermind, pp. 33 - 37. 